\title{
HUBUNGAN TINGKAT PENDIDIKAN DAN POLA ASUH ORANG TUA DENGAN PERKEMBANGAN PSIKOSOSIAL ANAK PRA SEKOLAH DI TK AL-ABIDIN BANYUANYAR SURAKARTA
}

\author{
Ratna Indriati ${ }^{1}$, Uun Puput Puspitasari ${ }^{2}$
}

\begin{abstract}
The task of psychosocial development of the preschool age is to foster a sense of initiative.To support the normal development required appropriate parenting and supported by parental education. The purpose of this study was to determine the correlation between education and parenting with psychosocial development.

The subjects were mother of the Kindergarten Al-Abidin Banyuanyar Surakarta.This research method of design correlation with cross sectional approach method. The sampling techniques are simple random sampling. The data obtained are then analyzed by chi square test with $p=0.05$.

The results of research showed Mothers with higher education level as many as 25 people $(56.82 \%)$ and intermediate 19 people $(43.18 \%)$, parenting democratic as many as 38 people (86.4\%) and non-democratic 6 people (13.6\%), children with appropriate psychosocial development as many as 37 child (84.1\%) and is not suitable 7 child $(15.9 \%)$. The correlation between education and psychosocial development obtained $p=$ 0.395 ( $p>0.05)$, which means that Ho is accepted, the correlation between of parenting and psychosocial development obtained $\mathrm{p}<0.001$ ( $p<0.05)$, which means $\mathrm{Ha}$ is accepted. It can be concluted that there is no relationship of the educational level with the psychosocial development and there is relationship of the parenting with the psychosocial development.
\end{abstract}

Keywords : Level of education, Parenting, Psychosocial Development

\section{PENDAHULUAN}

Anak usia prasekolah merupakan masa dimana anak sangat antusias untuk mempelajari hal-hal yang baru. Menurut Erikson tugas perkembangan psikososial anak usia pra sekolah adalah membina rasa inisiatif versus bersalah (Hidayat dan Uliyah, 2014). Anak yang berhasil dalam melaksanakan aktivitas dan memiliki perasaan bangga terhadap pencapaiannya akan membantu anak untuk menggunakan inisiatif (Kyle dan Carman, 2015), sehingga anak menjadi lebih mandiri dan memiliki kepercayaan diri. Sebaliknya anak yang kurang memiliki inisiatif akan menjadi anak yang tidak mandiri, pemalu, memiliki kemampuan sosialisasi yang buruk (Puspita, Suntari dan Astriani, 2012).
Peran orang tua dalam mengasuh anak sangat penting untuk mendukung perkembangan psikososial anak. Model pola asuh yang diterapkan akan membentuk kepribadian yang berbeda - beda sesuai dengan yang telah diajarkan orangtua, oleh karena itu diperlukan cara tepat untuk mengasuh anak (Soetjiningsih dan Ranuh, 2014).

Pola asuh orang tua terbagi dalam tipe demokratis, otoriter, dan permisif (Septiari, 2012). Tipe pola asuh orang tua berpengaruh pada perkembangan psikososial anak. Orang tua harus menerapkan pola asuh yang tepat supaya perkembangan psikososial anak normal pada fase inisiatif. Pada prinsipnya pola pengasuhan yang tepat adalah demokratis (Septiari, 2012), dan dari penelitian yang dilakukan Sopiah (2014), 
menunjukkan orang tua yang menerapkan pola asuh tipe demokratis mayoritas anak memiliki perkembangan psikososial pada fase inisiatif, sedangkan pada pola asuh permisif dan otoriter perkembangan psikososial anak mayoritas pada tahap rasa bersalah. Faktor lain yang mempengaruhi perkembangan anak yaitu pendidikan, menurut Septiari (2012), pendidikan orang tua merupakan salah satu faktor yang penting untuk tumbuh kembang anak, karena dengan pendidikan yang baik orangtua dapat menerima segala informasi mengenai pengasuhan anak yang baik sehingga perkembangan psikososial anak dapat berkembang pada fase inisiatif.

Pada Pendidikan Anak Usia Dini (PAUD) baik di KB maupun TK sering kita jumpai beberapa anak nampak memiliki kepercayaan diri yang baik yang ditunjukkan dengan anak mau berinteraksi dengan guru dan temannya tanpa malu-malu serta mengerjakan tugas tanpa dibantu, tapi juga ada anak yang tampak pemalu dan pendiam serta masih dibantu pada saat mengerjakan tugas di sekolah, dan biasanya anak - anak tersebut berasal dari keluarga dengan latar belakang pendidikan orang tua yang bervariasi, namun belum diketahui apakah adanya perbedaan kepercayaan diri yang dimiliki oleh anak - anak tersebut ada hubungannya dengan tingkat pendidikan dan pola asuh orang tua, oleh karena itu peneliti tertarik untuk melakukan penelitian mengenai hubungan tingkat pendidikan dan pola asuh dengan perkembangan psikososial anak usia pra sekolah.

\section{TUJUAN PENELITIAN}

Untuk mengetahui tingkat pendidikan orang tua, pola asuh orang tua dan hubungan tingkat pendidikan dan pola asuh dengan perkembangan psikososial anak usia pra sekolah di TK Al-Abidin Banyuanyar Surakarta.

\section{DESAIN PENELITIAN}

Penelitian ini merupakan penelitian korelasi dengan pendekatan cross sectional untuk mengetahui hubungan antara tingkat pendidikan dan pola asuh orang tua dengan perkembangan psikososial anak pra sekolah di TK Al-Abidin Banyuanyar.

\section{POPULASI, SAMPEL, DAN TEHNIK SAMPLING}

Populasi dalam penelitian ini adalah ibu dari anak TK B di TK Al-Abidin Banyuanyar yang berjumlah 50 orang. Pengambilan sampel menggunakan teknik simple random sampling dengan jumlah sampel penelitian ditentukan berdasarkan tabel Krecjie yaitu 44 orang.

\section{HASIL PENELITIAN}

Penelitian dilakukan pada bulan Mei sampai Agustus 2016 dengan hasil sebagai berikut :

Tabel 1.

Distribusi Frekuensi

Karakteristik Responden

\begin{tabular}{|c|c|c|c|}
\hline Karakte ristik & Kategori & $f$ & $\%$ \\
\hline \multirow{3}{*}{ Umur (tahun) } & $20-29$ & 4 & 9 \\
\hline & $30-40$ & 32 & 73 \\
\hline & $41-50$ & 8 & 18 \\
\hline \multirow[t]{4}{*}{ Pendidikan } & $<S M A$ & 0 & 0 \\
\hline & SMA & 19 & 43 \\
\hline & Diploma & 18 & 41 \\
\hline & Sarjana & 7 & 16 \\
\hline \multirow[t]{4}{*}{ Pekerjaan } & Guru & 9 & 20 \\
\hline & Swasta & 7 & 16 \\
\hline & PNS & 3 & 7 \\
\hline & Tidak Bekerja & 25 & 57 \\
\hline \multirow{2}{*}{$\begin{array}{l}\text { Jenis Kelamin } \\
\text { Anak }\end{array}$} & Laki-laki & 25 & 57 \\
\hline & Perempuan & 19 & 43 \\
\hline \multirow[t]{2}{*}{ Jumlah Anak } & $0-1$ & 6 & 14 \\
\hline & $>1$ & 38 & 86 \\
\hline
\end{tabular}


responden tidak bekerja, jenis kelamin anak lebih banyak laki laki, dan jumlah anak dalam keluarga sebagian besar lebih dari 1 (satu) anak.

Tabel 2.

Distribusi Frekuensi Tingkat

Pendidikan dan Pola Asuh Orang Tua

\begin{tabular}{lccc}
\hline $\begin{array}{l}\text { Variabel } \\
\text { Independen }\end{array}$ & Kategori & $\mathrm{f}$ & $\%$ \\
\hline Tingkat & Menengah & 19 & 43 \\
Pendidikan & Tinggi & 25 & 57 \\
Pola Asuh & Demokratis & 38 & 86 \\
& Non demokratis & 6 & 14
\end{tabular}

Dari tabel di atas dapat dicermati bahwa responden dengan tingkat pendidikan tinggi lebih banyak yaitu 25 orang (57\%) dan responden yang menerapkan pola asuh demokratis lebih banyak yaitu 38 orang (86\%).

Tabel 3.

Distribusi Frekuensi Perkembangan Psikososial Anak

\begin{tabular}{ccc}
\hline Perkembangan & $\mathrm{f}$ & $\%$ \\
Psikososial & & 84 \\
\hline Sesuai & 37 & 16 \\
Tidak sesuai & 7 & 100 \\
\hline Jumlah & 44 &
\end{tabular}

Berdasarkan tabel di atas diketahui bahwa jumlah anak yang memiliki perkembangan psikososial sesuai lebih banyak yaitu 37 anak (84\%) dibandingkan anak dengan perkembangan psikososial tidak sesuai yaitu 7 anak (16\%).

Tabel 4.

Hubungan Tingkat Pendidikan Dengan Perkembangan Psikososial Anak

\begin{tabular}{ccccc}
\hline Perkembangan & Sesuai & $\begin{array}{c}\text { Tidak } \\
\text { sesuai }\end{array}$ & Total & $\mathrm{p}$ \\
Tk. Penddk & & 2 & 19 & 0,395 \\
\hline Menengah & 17 & 5 & 25 & \\
\hline Tinggi & 20 & 5 & 44 & \\
\hline Total & 37 & 7 &
\end{tabular}

Dari tabel di atas dapat dianalisa :

1. Responden dengan tingkat pendidikan menengah sebanyak 19 ibu, dari jumlah tersebut terdapat 17 anak dengan perkembangan psikososial sesuai dan 2 anak tidak sesuai.

2. Jumlah responden dengan tingkat pendidikan tinggi sebanyak 25 ibu, dari jumlah tersebut terdapat 20 anak dengan perkembangan psikososial sesuai dan 5 anak tidak sesuai.

Dari hasil uji Chi-Square program SPSS versi 18.0 dengan $\alpha=5 \%$ (0.05) diperoleh $p$ sebesar 0.395 sehingga nilai $p>0.05$, yang berarti Ho diterima sehingga tidak ada hubungan tingkat pendidikan dengan perkembangan psikososial anak.

Tabel 5.

Hubungan Pola Asuh Dengan Perkembangan Psikososial Anak

\begin{tabular}{ccccc}
\hline Rerkembangan & Sesuai & $\begin{array}{c}\text { Tidak } \\
\text { sesuai }\end{array}$ & Total & $P$ \\
\hline $\begin{array}{c}\text { Demokratis } \\
\text { Non }\end{array}$ & 35 & 3 & 38 & 0,000 \\
demokratis & 2 & 4 & 6 & \\
\hline Total & 37 & 7 & 44 & \\
\hline
\end{tabular}

Dari tabel di atas dapat dianalisa bahwa :

1. Jumlah responden dengan pola asuh demokratis sebanyak 38 ibu, dari jumlah tersebut terdapat 35 anak dengan perkembangan psikososial sesuai dan 3 anak tidak sesuai.

2. Jumlah responden dengan pola asuh non demokratis sebanyak 6 ibu, dari jumlah tersebut terdapat 2 anak dengan perkembangan psikososial sesuai dan 4 anak tidak sesuai.

Dari hasil uji Chi-Square program SPSS versi 18.0 dengan $\alpha=5 \%$ (0.05) diperoleh $p$ sebesar $<0.001$ sehingga nilai $p<0.05$, yang berarti $\mathrm{H}_{\mathrm{a}}$ diterima sehingga ada hubungan pola asuh dengan perkembangan psikososial anak. 


\section{PEMBAHASAN}

1. Tingkat Pendidikan

Dalam penelitian ini tingkat pendidikan responden berada pada kategori pendidikan menengah dan pendidikan tinggi, hal ini dikarenakan tidak adanya responden dengan tingkat pendidikan dasar. Latar belakang pendidikan responden yang dikategorikan dalam pendidikan tinggi adalah Diploma dan Sarjana. Dari hasil penelitian menunjukkan jumlah responden dengan pendidikan tinggi lebih banyak yaitu 25 orang, sedangkan responden dengan pendidikan menengah berjumlah 19 orang.

Pendidikan orang tua merupakan salah satu faktor yang mempengaruhi perkembangan anak. Orang tua yang mempunyai latar belakang pendidikan yang tinggi akan lebih memperhatikan segala perubahan, dan setiap perkembangan yang terjadi pada anaknya (Septiari, 2012), sehingga pada umumnya orang tua dengan latar belakang pendidikan yang tinggi akan menerapkan pola asuh yang tepat sehingga mendukung perkembangan anak yang optimal, sedangkan pendidikan yang kurang akan menghambat perkembangan sikap orang tua terhadap nilai - nilai yang harus diperkenalkan sehingga akan membentuk suatu kepribadian anak yang kurang baik dan perkembangan psikososial anak menjadi tidak optimal.

2. Pola Asuh

Pada penelitian ini pola asuh orang tua dikategorikan dalam pola asuh demokratis dan pola asuh non demokratis, yang dikelompokkan dalam pola asuh non demokratis adalah pola asuh selain demokratis yaitu pola asuh otoriter, permisif, dan campuran.
Hasil analisa univariat pola asuh orang tua menunjukkan hampir seluruh responden melakukan pola asuh demokratis yaitu sebanyak 38 orang (86\%). Pola asuh demokratis merupakan pola pengasuhan dimana orang tua mendorong anak untuk menjadi mandiri tetapi tetap memberikan batasan atau aturan serta mengontrol perilaku anak. Orang tua bersikap hangat, mengasuh dengan penuh kasih sayang serta penuh perhatian. Pola asuh demokratis merupakan pola asuh yang ideal atau baik karena dampak psikologi dari pola asuh ini bagi anak adalah rasa harga diri yang tinggi, memiliki moral yang standar, kematangan psikologisosial, kemandirian dan mampu bergaul dengan teman sebayanya (Septiari, 2012). Hal ini seperti ditunjukkan dari hasil penelitian yang dilakukan oleh Trisusilaningsih (2009), dimana sebagian besar responden penelitian sudah menerapkan pola asuh yang demokratis $(58,8 \%)$ dan sebagian besar anak memiliki perkembangan moral yang baik. Demikian juga penelitian yang dilakukan oleh Handayani (2015), menunjukkan bahwa perkembangan emosi anak yang paling baik adalah anak dengan pola asuh demokratis.

Pada penelitian ini pola asuh demokratis merupakan pola asuh yang paling banyak dilakukan juga oleh responden. Dari analisa yang dilakukan peneliti, sebagian besar responden sudah menerapkan pola asuh demokratis dikarenakan adanya beberapa faktor pendukung diantaranya usia, dimana sebagian besar responden (73\%) berada pada usia dewasa yaitu usia 30 - 40 tahun. Pada usia tersebut seseorang sudah memiliki kematangan dalam 
berfikir dan bertindak sehingga hal ini mempengaruhinya dalam menjalankan peran sebagai orang tua khususnya dalam pengasuhan yang lebih optimal. Hal lain yang bisa mendukung yaitu keterlibatan orang tua dimana sebagian besar responden (57\%) adalah ibu rumah tangga yang mempunyai banyak waktu bersama anak dan didukung dengan pendidikan ibu dimana tidak ada ibu dengan latar belakang pendidikan dasar. Ibu yang terlibat langsung dalam pengasuhan pada anak dan didukung dengan pendidikan orang tua yang baik akan lebih mampu memperhatikan segala perubahan dan setiap perkembangan anaknya sehingga memampukan ibu untuk melakukan pola asuh yang baik.

3. Perkembangan Psikososial Dalam penelitian ini perkembangan psikososial dikategorikan menjadi 2 (dua) yaitu kategori sesuai dimana perkembangan psikososial berada pada tahap inisiatif dan kategori tidak sesuai yaitu perkembangan psikososial tidak sesuai dengan tahap inisiatif. Hasil penelitian yang telah dilakukan menunjukkan bahwa perkembangan psikososial anak TK Al-Abidin Banyuanyar, pada kategori sesuai dengan jumlah 39 anak dan tidak sesuai berjumlah 5 anak. Dari hasil penelitian tersebut menunjukkan bahwa jumlah anak di TK Al-Abidin Banyuanyar yang memiliki perkembangan psikososial normal lebih banyak.

4. Hubungan Tingkat Pendidikan dan Perkembangan Psikososial Berdasarkan analisa statistik diperoleh $p$-value sebesar 0,395 $(p>0,05)$ yang berarti tidak ada hubungan antara tingkat pendidikan dengan perkembangan psikososial anak. Berdasarkan analisa data menunjukkan dari 25 lbu yang berpendidikan tinggi terdapat $80 \%$ yang memiliki anak dengan perkembangan psikososial yang sesuai, demikian juga pada ibu yang berpendidikan menengah lebih banyak yang memiliki anak dengan perkembangan psikososial yang sesuai yaitu $89 \%$. Dari hasil tersebut bisa diketahui bahwa pada orang tua yang berpendidikan menengah maupun tinggi sama - sama memiliki anak dengan perkembangan psikososial normal dengan jumlah yang lebih banyak dibandingkan anak dengan perkembangan psikososial yang tidak sesuai. Hasil tersebut menunjukkan bahwa tingkat pendidikan responden tidak ada hubungannya dengan perkembangan psikososial anak karena perkembangan psikososial anak secara keseluruhan baik pada orang tua yang berpendidikan tinggi maupun menengah berada pada tahap inisiatif (perkembangan normal). Hal ini dimungkinkan karena untuk perkembangan psikososial anak bukan hanya dipengaruhi oleh tingkat pendidikan orang tua saja tapi masih ada faktor lain yang juga bisa mempengaruhinya dan menunjang tingkat pendidikan responden dalam penelitian ini yaitu faktor jenis kelamin anak, pengalaman ibu dalam merawat anak, dan status bekerja ibu.

Berdasarkan hasil penelitian ini menunjukkan bahwa sebagian besar responden memiliki anak dengan jenis kelamin laki - laki yaitu 25 orang (57\%). Menurut Soetjiningsih dan Ranuh (2014), anak laki - laki lebih aktif bila dibandingkan anak perempuan, 
hal ini diperlukan untuk mendukung perkembangan psikososial pada usia prasekolah dimana salah satu tugas perkembangannya adalah berani dan mandiri. Demikian juga menurut Lange dan Jakubowski dalam penelitian Karnadi (2009), anak laki - laki cenderung memiliki sifat agresif, cenderung kompetitif, percaya diri, ingin tampil dan mandiri yang lebih tinggi dibandingkan anak perempuan Kecenderungan ini menjadikan anak laki - laki lebih sering mengekspresikan diri secara terbuka tanpa rasa takut dan salah. Karakter lain adalah anak laki - laki serta dari hasil penelitian menunjukkan anak laki - laki memiliki kemampuan yang lebih baik dalam mengemukakan pendapat di depan kelas dibandingkan anak perempuan, hal ini juga diperlukan untuk mendukung perkembangan psikososial yang normal.

Faktor lain yaitu adanya kedekatan antara orang tua dengan anak, komunikasi dan hubungan antara orang tua dengan anak sangat penting untuk perkembangan anak khususnya perkembangan psikososial (Soetjiningsih dan Ranuh, 2014). Dalam penelitian ini sebagian besar responden tidak bekerja / sebagai ibu rumah tangga yaitu 25 orang (57\%). Hasil penelitian yang dilakukan oleh Briawan dan Herawati (2008), bahwa terdapat hubungan positif yang nyata antara stimulasi dengan perkembangan anak. Dengan interaksi orang tua dan anak yang sering, yang cenderung dilakukan oleh orang tua yang tidak bekerja, maka orang tua memiliki waktu yang lebih banyak untuk memberikan stimulasi.

Selain faktor di atas juga adanya faktor pengalaman ibu dalam merawat anak. Dari hasil penelitian ini sebagian besar responden memiliki anak lebih dari satu yaitu 38 orang (86\%). Dengan jumlah anak lebih dari satu maka responden sudah mempunyai pengalaman sebelumnya dalam merawat anak. Hal ini sesuai dengan teori yang disampaikan oleh Soetjiningsih dan Ranuh (2014), bahwa salah satu faktor yang mempengaruhi perkembangan anak adalah jumlah anak dalam keluarga. Dengan jumlah anak lebih dari satu memungkinkan responden lebih siap dalam melakukan pengasuhan pada anak.

Berdasarkan analisa di atas menunjukkan tidak adanya hubungan antara tingkat pendidikan dengan perkembangan psikososial anak TK Al-Abidin Banyuanyar dimungkinkan karena selain faktor pendidikan ada faktor lain yang ditemukan dalam penelitian ini yaitu jenis kelamin anak, status bekerja ibu, dan pengalaman ibu sebelumnya dalam merawat anak yang ikut berkontribusi dalam mendukung perkembangan psikososial anak sehingga baik pada ibu yang berpendidikan tinggi maupun berpendidikan menengah sama sama memiliki anak dengan perkembangan psikososial normal yang lebih banyak dibandingkan anak dengan perkembangan psikososial yang tidak sesuai.

5. Hubungan Pola Asuh dan Perkembangan Psikososial

Dari hasil uji Chi-Square diperoleh $p$-value sebesar $<0,001 \quad(p<0,05) \quad$ yang menunjukkan ada hubungan positif dan signifikan antara pola asuh orang tua dengan perkembangan psikososial anak. Menurut Hidayat dan Uliyah 
(2014), salah satu faktor yang mempengaruhi perkembangan psikososial adalah kelompok (keluarga) dalam melakukan pola asuh. Dalam masa pertumbuhan dan perkembangan, anak perlu diasuh dan dibimbing oleh orang dewasa dalam lingkungan kehidupan keluarga. Tipe pola asuh yang tepat akan mendukung perkembangan anak menjadi optimal.

Dari penelitian yang dilakukan oleh Qistiana, Nurlaila, dan Utami (2016), menunjukkan bahwa sebagian besar anak mendapatkan pola asuh demokratis $(50 \%)$ dan sebagian besar anak memiliki perkembangan psikososial yang baik (62,9\%). Hal ini menunjukkan bahwa pola asuh orang tua yang demokratis membantu anak untuk memiliki perkembangan psikososial yang baik. Demikian juga penelitian yang dilakukan oleh Utami (2008), menunjukkan ada hubungan antara tipe pola asuh dengan perkembangan psikososial anak prasekolah, dan tipe pola asuh yang terbanyak dilakukan oleh responden adalah tipe pola asuh demokratis (40\%). Berdasarkan jawaban responden dalam penelitian ini, sebagian besar orang tua dari anak TK Al Abidin sudah melakukan pengasuhan yang tepat yang ditunjukkan dari $52 \%$ orang tua selalu menegur dan mengingatkan anak ketika anak melakukan kesalahan, 50\% orang tua selalu menghargai prestasi anak di sekolah dan menghargai usahanya, $77 \%$ mengharapkan anak bersikap mandiri dan mengkomunikasikan peraturan secara jelas dan langsung. Dengan menerapkan tipe pola asuh demokratis maka anak akan tumbuh menjadi anak yang mandiri, tegas terhadap diri sendiri, ramah dengan teman sebayanya, mau bekerjasama dengan orang tua serta memiliki motivasi yang kuat untuk maju (Septiari, 2012). Hubungan yang baik antara anak dengan orang tuanya akan menjadi dasar utama bagi anak untuk membangun hubungan baik dengan lingkungan/orang lain, memiliki kehidupan sosial dan konsep diri yang positif. Jadi di dalam keluarga anak akan mendapatkan bekal yang memungkinkannya menjadi anggota masyarakat yang baik. Pola asuh yang tepat akan mendukung perkembangan psikososial anak menjadi inisiatif. $\mathrm{Hal}$ ini sesuai dengan hasil penelitian yang dilakukan oleh Istiqomah (2012), dimana anak prasekolah yang mendapatkan pola asuh demokratis memiliki perkembangan psikososial pada tahap inisiatif. Dengan demikian tipe pola asuh yang diterapkan orang tua pada anaknya menentukan keberhasilan perkembangan psikososial dari anak. Orang tua yang salah dalam menerapkan pola asuh akan bisa mengakibatkan kegagalan dalam pembentukan perkembangan psikososial yang normal pada anak prasekolah yaitu pada tahap inisiatif.

\section{KESIMPULAN}

1. Orang tua pada anak TK Al Abidin yang memiliki latar belakang pendidikan tinggi lebih banyak yaitu $56,82 \%$ dan pola asuh terbanyak yaitu tipe demokratis $(86,4 \%)$.

2. Perkembangan psikososial anak lebih banyak pada perkembangan yang sesuai (tahap inisiatif) yaitu $84,1 \%$.

3. Tingkat pendidikan responden tidak memiliki hubungan dengan perkembangan psikososial anak $(p=0,395)$. 
4. Tipe pola asuh responden memiliki hubungan positif yang signifikan dengan perkembang an psikososial anak $(p<0,001)$.

\section{SARAN}

1. Bagi orang tua diharapkan peka terhadap kebutuhan anak, menggunakan tipe pola asuh demokratis, dan senantiasa aktif dalam mencari informasi mengenai pengasuhan yang tepat pada anak.

2. Bagi pihak sekolah dan guru diharapkan selalu memberikan umpan balik dan ikut mendukung orang tua dalam menerapkan pola asuh yang demokratis.

3. Bagi Peneliti selanjutnya supaya memasukkan faktor-faktor lain selain pola asuh dan tingkat pendidikan sebagai variabel independen dalam penelitian.

\section{DAFTAR PUSTAKA}

Briawan, D. dan Herawati, T. 2008. "Peran Stimulasi OrangTua Terhadap Perkem bangan Anak Balita Keluarga Miskin". Jurnal IPB Vol. 1 No. 1. Diakses 18 Agustus 2016.

Handayani, A. S. N. 2015. Perkembangan Emosi Ditinjau Dari Pola Asuh Orang Tua Pada Anak Kelompok B Raudhatul Athfal di Kecamatan Kalijambe Sragen.

http://Eprints.ums.ac.id. Diakses 15 Agustus 2016

Hidayat, A. A. A. dan Uliyah, M. 2014. Pengantar Kebutuhan Dasar Manusia, edisi 2. Salemba Medika, Jakarta.

Istiqomah, S. N. 2012. Hubungan Pola Asuh Orang Tua dan Perkembangan Kognitif dan Psikososial Anak Usia Pra Sekolah di TK Plus Mutiara IImu Pandaan Pasuruan. www.journal.unipdu.ac.id/inde x.php/eduhealth/article/ view/125. Diakses 2

Desember 2015.

Karnadi. 2009. Pengaruh Jenis

Kelamin dan Kreativitas

Terhadap Kemampuan

Mengemukakan Pendapat

Anak Kelas Rendah di Sekolah Dasar.

Ejournal.unesa.ac.id/article/vie w. Diakses Juli 2016.

Kyle, T. dan Carman, S. 2015. Buku Ajar Keperawatan Pediatri, edisi 2. Alih bahasa Devi Yulianti. EGC, Jakarta.

Puspita, A., Suntari, N. L. P. Y. dan Astriani, N. L. P. N. 2012. "Hubungan Pola Asuh Orang tua Dengan Kepercayaan Diri Pada Anak Prasekolah di TK IV Saraswati Denpasar". Jurnal Universitas Udayana Denpasar. Diakses 20 Desember 2015.

Qistiana, R., Nurlaila dan Utami, W. 2016. Hubungan Tipe Pola Asuh Orang Tua Dengan Perkembangan Psikososial Anak Usia Prasekolah di TK Pertiwi 1 Purbowangi Buayan Kabupaten Kebumen. Skripsi.

Septiari, B. B. 2012. Mencetak Balita Cerdas dan Pola Asuh Orang Tua. Nuha Medika, Yogyakarta.

Soetjiningsih dan Ranuh, G. Tumbuh Kembang Anak. Edisi II. Jakarta: EGC, 2014.

Sopiah. 2014. Hubungan Tipe Pola Asuh Pengganti lbu : Keluarga Terhadap Perkembangan Psikososial Anak Usia Prasekolah di Kecamatan Sukalarang Sukabumi. Skripsi. Universitas Islam Negeri Syarif Hidayattullah, Jakarta.

Trisusilaningsih. 2009. Pengaruh Pola Asuh Orang Tua Terhadap Perkembangan Moral Anak di TK ABA Sidomulyo. http://mardiya.wordpress.com. Diakses 15 Agustus 2016. 
••KOsคเn״ JIK. Vol. 4 No. 2 September 2016

Utami, R. B. 2008. Pengaruh Tingkat Pendidikan dan Tipe Pola Asuh Orang Tua Terhadap Perkembangan Psikososial Anak Pra Sekolah di TK Aisyiyah II Nganjuk. Tesis. Universitas Sebelas Maret, Surakarta. STIKES Muhammadiyah Gombong.

${ }^{1}$ Dosen Akper Panti Kosala

Surakarta

${ }^{2}$ Mahasiswa Akper Panti Kosala

Surakarta 